\title{
Conclusion: Orientalism Interrupted
}

The socialist conception of the revolutionary process is characterized by two fundamental features that Romain Rolland has summed up in his watchword: "pessimism of the intellect, optimism of the will."

Antonio Gramsci, L'ordine nuovo (1920)

Frantz Fanon, the Martiniquan psychiatrist who served in an Algerian hospital during the French-Algerian war, gives us in L'an cinq de la révolution algérienne (1959) a study of how objects and practices that had been used previously by the colonizing power can be appropriated by the "native" group seeking independence. He describes how apparatuses that began as vehicles of French oppression, such as the radio, medical practices, or law enforcement, were reappropriated by the Algerians and turned to serve in the war against the French. When forms within the native culture, such as the women's custom of wearing veils or the patriarchal structure of the Algerian family, were manipulated or exploited by the colonizing forces, the Algerians were able to redefine their meaning and to practice them differently, in order to make themselves less vulnerable to French rule and to struggle more effectively against French colonialism. ${ }^{1}$ Fanon explains, for example, that until 1945 the radio had represented the voice of the occupier-Frenchmen speaking to Frenchmen-a system of signs that

1For a feminist analysis of Fanon's discussion of the French attempt to raise the veils of Algerian women, see Winifred Woodhull's "Unveiling Algeria," Genders (1991; in press). 
altogether excluded Algerians. As the Algerian struggle against the French occupation developed, however, Algerians began to listen to the French news reports in order to gain a sense of the progress of the revolution. In the French broadcasts' fabrications and distortions, Algerians were able to read the degree to which the occupiers were threatened. Radio became a means of measuring "the dying colonialism"; it became essential for the Algerians to be informed, both of the French losses and of their own. By 1956 Algerians of all economic levels were buying radio receivers; indeed, listening to the radioeven when the wavelengths that the Algerians depended on had been jammed and it was impossible to hear anything but static-became a signifier of Algerian commitment to the revolution itself.

In the preceding chapters I have located moments of intersection, conflict, multivalence, and incommensurability that illustrate the heterogeneity of the orientalist terrain. It has been my contention throughout that these moments represent the vulnerability of orientalist formations. Although these readings of destabilized moments of orientalism provide a starting point for articulating resistance, one finds among theorists of decolonization, subalternity, feminism, and minority discourse even more explicit and suggestive discussions of the possibilities for opposition to and transformation of cultural domination. In foregrounding the locations of dissent and the emergent spaces of the oppressed, Fanon's text offers an explicit mandate in a way that Foucault's notion of heterotopia does not; that is, his narrative makes evident the spaces of otherness on the social terrain from which transforming interventions may be articulated. Fanon's account grounds literary and theoretical analysis by focusing on explicit practices of dissent that produce significant changes to an existing colonialist hegemony, and by further emphasizing that the social and discursive locations of dissent are of utmost importance in the dismantling of colonialism. The account of the Algerian adaptation of the radio illustrates remarkably well the principle discussed throughout-that cultural shifts can be achieved through the appropriation and rearticulation of existing cultural objects or practices, for these objects and practices signify differently depending on social context and on whether they are articulated by dominant or emergent relations of representation. Furthermore, the insertion of an object into a new practice does not simply shift the meaning of the object, such as the 
radio's signifying initially the presence of the French colonialists and ultimately the presence of Algerian commitment to revolution. The rearticulated practice of Algerians listening to the radio also transformed the very construction of meaning under French colonialism, the ways in which meaning was attached to objects; that is, it destabilized the formerly secure connection between French objects and French rule. Fanon offers a practical and historical example of how the struggle for meaning in discourse forms an integral part of the struggle for hegemony. One can see how the dialogues between the Indian and Anglo-American scholars discussed in Chapter 4 exemplify a structurally, though not materially, analogous struggle for meaning; in their various claims to the right to interpret Forster's novel and, finally, to define the significance of India, the Indian scholars appropriate the objects and practices of the colonialist discourse and rearticulate a system of signs that had formerly excluded them.

Like Fanon, the Subaltern Studies Group, a group of contemporary Indian historians, is also concerned with positionality, or the question of from where interventions in "official" narratives are made, and in this sense they extend the present discussion of orientalism as a heterogeneous discursive terrain. The Subaltern Studies Group's concern with the problem of subalternity takes place in a more textual arena than Fanon's, however, in that their project is historiographic. Having specifically taken up Gramsci's notion of subalternity as the emergent classes whose practices are identified only when viewed with historical hindsight, they have targeted as their arena of contestation the way in which the history of Indian independence is told, from whose point of view, and with what materials. Within the context of the historiography of Indian nationalism and independence, they take subalternity to mean not simply the situations of the Indians vis-à-vis the British imperialists but, more specifically, the role of the masses of Indian peasants and urban poor, whose demonstrations of resistance have not been as celebrated as those of the Indian elite, and indeed whose means of articulating resistance to British rule were quite different from those of the Indian landlords and bourgeois nationalists. The project of the Subaltern Studies Group is to rewrite the history of Indian independence from the point of view of these voiceless insurgent masses, in defiance of historical accounts that place either Indian elites or British colonialists as the primary subjects of history. The 
Group's histories of peasant rebellions and worker revolts narrate some of what is missing from official histories; they contest the totalizing authority of elite histories and assert, as Dipesh Chakrabarty does, that "ruling-class documents often used for historical reconstructions of working-class conditions can be read both for what they say and for their 'silences.' "2 2 Thus, they reconstitute other versions of history from these "silences," as well as by rereading historical materials such as letters, state archives, public health reports, district handbooks, or Labour Department files in ways that are informed by attention to these silences. Their interventions work to unmask and displace the colonialist ideology of official historical narrative.

It is worth remembering, however, that subalternity is, in Gramsci's account, unclosed, episodic, and in process; the subaltern masses and their histories, by definition, cannot be fixed and narrated. Like the dominant component of the hegemonic process to which it is inextricably bound, subalternity is always emerging and in flux. To the degree that some of the narratives of these radical historians posit an insurgent subject of history as they chart the progress of the working class or peasant masses, they, like official historians, risk reducing and appropriating subalternity. For the process of narration inevitably effaces and displaces the untextualizable properties of subaltern historical material. For this reason certain historians of the Subaltern Group are suspicious of seamless narratives and essentialized subjects (such as the "Indianness of the native point of view" posited by Vasant Shahane), and prefer to render history in terms of struggles and contradictions, in order that their histories do not appropriate and neutralize the agents of subaltern struggles. Others consider that the positing of a subaltern subject may be a necessary and strategic fixing of subalternity for the political purposes of launching a critique of official history and its structures of exclusion. In his analysis of the semiotic codes of colonialist discourse, "The Prose of Counter-Insurgency," Ranajit Guha foregrounds this dilemma, explaining that even the history of insurgency, like colonialist historiography, "excludes the rebel as the conscious subject of his own history," for an "abstraction called Worker-and-Peasant, an ideal rather than the real historical

2Dipesh Chakrabarty, "Conditions for Knowledge of Working-Class Conditions," in Guha and Spivak, Selected Subaltern Studies, p. 179. Chakrabarty and other radical historians of the Subaltern Studies Group are represented in this volume. 
personality of the insurgent" is made to replace the specific rebel forces, with their conflicts and contradictions. ${ }^{3}$ Yet Guha ultimately argues for the political importance of positing such an ideal, and for the strategic necessity of inserting the ideal into a constructed chronology for the purpose of displacing official narrative and the ideological domination that it represents.

Gayatri Spivak further elaborates the "strategic use of a positive essentialism in a scrupulously visible political interest." Spivak explains that if the representation of subaltern subjectivity is "strategic," and such a subjectivity is posited while one simultaneously acknowledges that subalternity is by definition always unstable and heterogeneous to the narrative project of any historian, then this accomplishes an "affirmative deconstruction." If, by contrast, "the restoration of the subaltern's subject-position in history is seen by the historian as the establishment of an inalienable and final truth of things, then [this restoration will] inevitably objectify the subaltern and be caught in the game of knowledge as power." 4 The practice of strategic essentialism, then, as an "affirmative deconstruction" inserts a variety of insurgent subjects into historical discourse, and in the same move metaphorically brackets or annuls these insertions. By bracketing and suppressing subalternity-as-essence, the very same gesture by which the historian calls the subaltern subject into being in turn calls it into question. That gesture accomplishes an articulation of subaltern identity as a point of opposition to cultural domination yet avoids reducing or compromising the subaltern subject's state of persistent emergence. By inserting a number of different subjects and writing the histories of their struggles-peasant movements, workers' revolts-strategic essentialism also multiplies the terrain of the history of dissent, positing subjects without privileging the singularity or centrality of any one.

The Subaltern historian's problematic relationship to subalternity is not dissimilar to the relationship of critical readers of orientalism to the critical category of otherness, and indeed Spivak's discussion of strategic essentialism is instructive for my own discussion of reconstructing

\footnotetext{
3Ranajit Guha, "The Prose of Counter-Insurgency," in Guha and Spivak, Selected Subaltern Studies, p. 77.

"Gayatri Spivak, "Subaltern Studies: Deconstructing Historiography," in In Other Worlds, pp. 205, 207.
} 
orientalism. Just as the Subaltern historian's insertion of a subaltern subject into historical narrative risks reducing and fetishizing subalternity, the critical problem of demystifying the discursive management and production of otherness is fraught with similar difficulties. For if one's task is in part to identify constituted otherness, one must take care to do this work of identification without reiterating, in the analysis of the formation, the apparatuses of management and exclusion, without overdetermining such otherness according to the very structures and disciplines that one wishes to displace. The practice of strategic essentialism suggests that it is possible for one to posit certain historically and textually specific essentialized notions of othernessfor example, the Orient, woman, the poor, the colonized-in order to challenge the discourses that produce such notions, while nonetheless placing the notion of the Other under erasure so as to ensure that such essentialisms will not be reproduced and proliferated by those very efforts to criticize their use.

It is not insignificant that one of the more important formulations of subalternity should come from Gayatri Spivak, a theorist whose body of work is not exclusively concerned with subaltern criticism but rather with theorizing the nexus of anticolonialism, deconstruction, marxism, and feminism. At this particular moment in the history of theory, I believe that feminist theory contains the most suggestive analyses of the problems of positionality, intersection, and multivalence. ${ }^{5} \mathrm{I}$ am referring here to feminist projects-in addition to Spivak's those of Trinh T. Minh-ha, Donna Haraway, or Evelyn Nakano Glenn-for which the focus is not exclusively the topics of women, gender, and sexuality, but in which issues such as poverty, classism, racism, and

\footnotetext{
5It is clear to any reader of feminist theory that what I refer to as feminism does not represent a homogeneous ideology, agenda, or approach, although it includes-but is not limited to-theories and practices that address the situation and construction of women in a number of arenas: social, cultural, literary, economic, and historical. Feminist concerns range from the struggle for reproductive rights, to psychoanalytic discussions about sexual difference, to rewriting history in terms of women as agents of history, to critiques of the implicit gendering of academic disciplines and fields of knowledge, to theories of gay and lesbian subjectivities, to studies of female domestic space in the novel. Yet feminist attention is also directed toward the feminization of poverty, the concentration of women of color in domestic labor and service jobs, the conditions of women in Asia, Africa, and Latin America. Thus, feminism is remarkable in the degree to which it has theorized and comprehended that gender is inextricably linked to inscriptions of class, race, and nationality, perhaps because it is evident that many women are poor, are workers, are of different races, are colonized.
} 
colonialism are approached as feminist issues in the sense that the critiques of the oppression and exclusion of workers, men and women of color, and colonized populations are seen to be congruent with or implicated in the critique of sexism. This type of feminist theory is the least restrictive, and perhaps the most capable-among other paradigms of analysis, such as Marxism, anticolonialism, or psychoanalysis-of accounting for and theorizing heterogeneity to the degree that it considers a privileged category, gender, to be a powerful valence of human subjectivity, yet at the same time to be inseparable from other classifications such as class, race, or nationality.

Some of the feminist theorists who address the question of intersecting discursive formations do so through a discussion of gendered subjectivity, or the multiplicity of social relations across which a subject is constructed and signified. These theorists take as a fundamental premise that gender as a social classification is not produced in isolation; rather, its articulation is always also linked to the constructions of race, class, caste, nationality, and so forth. Teresa de Lauretis, for example, theorizes gendered subjectivity as both an active construction and a discursively mediated political interpretation of one's history. ${ }^{6}$ For de Lauretis, all subjects are semiotic productions, both the result and the condition of the social production of meaning. The construction of subjectivity is in process, in that each position of the dialectic-the complex of practices she calls "experience" and the set of social relations-shifts and alters as the subject is signified. In Technologies of Gender (1987), de Lauretis elaborates her description of the gendered subject as "multiple," as simultaneously a racial, ethnic, and class-determined subject: "Feminist understanding: that the female subject is en-gendered, constructed and defined in gender across multiple representations of class, race, language, and social relations; and that, therefore, differences among women are differences within women, which is why feminism can exist despite those differences and, as we are just beginning to understand, cannot continue to exist without them."7 Conceived as multiple, rather than divided or unified, the subject theorized by de Lauretis's feminism is not only a subject-in-process but, more important, a subject that occupies dis-

6Teresa de Lauretis describes her project in these terms in her article "The Essence of the Triangle or, Taking the Risk of Essentialism Seriously: Feminist Theory in Italy, the U.S., and Britain," in differences 1, no. 3 (Summer 1989).

${ }^{7}$ Teresa de Lauretis, Technologies of Gender: Essays on Theory, Film, and Fiction (Bloomington: Indiana University Press, 1987), p. 139. 
tinctly different social positions at different moments, and at times several positions at once. Because it is multiply inscribed, the subject theorized by de Lauretis remains undetermined by any single discursive apparatus; by virtue of its multiplicity, this subject cannot be totalized as it exceeds dominant discursive formations, is always both inside and outside the apparatuses that inscribe any particular category, such as its gender, race, or class.

This suggests political implications beyond the narrower concern of de-essentializing female identity, namely that subjects conceived as multiply constructed are capable of a range of commitments. They may act, for example, at one time for feminist issues, while at others for racial or ethnic groups, for labor unions, or in anticolonialist or antiwar activities. The notion of a subject who represents the juncture of a multiplicity of social contradictions allegorizes the possibility of a site across which different counterhegemonic movements may be affiliated, through which diverse groups and sectors may cooperate to form a "new historical bloc." In this regard, theorists of coalition politics and minority discourse in Europe and the United States have elaborated Gramsci's notion in order to define a common agenda that could bring together heterogeneous minorities-racial and ethnic groups, women, postcolonial populations-who suffer political and material marginality in relation to dominant institutions. ${ }^{8}$ Furthermore, the concepts of hybrid subjectivity and minority coalitions thematize not only a heterogeneity of counterhegemonic interests, but also, more strategically, the heterogeneity of different "fronts" in which the struggles of cultural politics, feminism, or anticolonialism may take place - the neighborhood, the workplace, the university, the picket line-and the necessity of not privileging a single site or struggle to the exclusion or suppression of others.

8See Stuart Hall, "Gramsci's Relevance for the Study of Race and Ethnicity," Journal of Communication Inquiry 10 (1986): 5-27; Abdul JanMohamed and David Lloyd, "Introduction: Toward a Theory of Minority Discourse: What Is to Be Done?" in The Nature and Context of Minority Discourse, ed. JanMohamed and Lloyd (Oxford: Oxford University Press, 1990); and Radhakrishnan, "Toward an Effective Intellectual."

For discussions of new historical blocs from the perspectives of specific minority communities, see, for example, George Lipsitz, "Cruising around the Historical Bloc: Postmodernism and Popular Music in East Los Angeles," in Time Passages: Collective Memory and American Popular Culture (Minnesota: University of Minnesota Press, 1990); Cornel West, "Marxist Theory and the Specificity of Afro-American Oppression," in Marxism and the Interpretation of Culture, ed. Lawrence Grossberg and Cary Nelson (Urbana: University of Illinois Press, 1988); and Lisa Lowe, "Heterogeneity, Hybridity, Multiplicity: Marking Asian American Differences," Diaspora: A Journal of Transnational Studies 1 (Spring 1991): 24-44. 
Fanon, the Subaltern Studies Group, the feminist discussion of multiplicity-each represents postcolonial theories of resistance that contextualize the meanings of the discursive instabilities identified in the preceding chapters by offering examples in which multivalence and heterogeneity constitute the bases of significant transformations of existing hegemonies. These postcolonial theorists write from sites other than the European contexts of the theorists Foucault and Gramsci, with whom I opened my discussion of orientalism, and in this they symptomatize the "heterotopical" property of discursive terrains. Fanon's description of the multivalent meaning of the radio during the French-Algerian war provides a historical and material example of how the appropriation and rearticulation of objects and practices, discussed in textual terms in the foregoing chapters, can alter the structure and the distribution of power; the example of the radio further foregrounds the importance of the political and geographic locations of these oppositional practices. The multivalence of signs is likewise emphasized by the Subaltern Studies Group. The practice of "strategic" essentialism described by Guha and Spivak suggests that it is possible to constitute specific signifiers of otherness, such as Indianness, for the purpose of disrupting the discourses that exclude Indians as Other while simultaneously revealing the internal contradictions and slippages of "Indianness" so as to ensure that the signifier Indianness will not be reappropriated by the very efforts to criticize its use. In light of the discussion in Chapter 4 of the different constructions of Indianness deployed by Anglo-American and Indian critics, Guha and Spivak's deconstruction of "subalternity" may be considered as constituting a more contemporary third discussion of Indian "difference," one that provides critical commentary on the practices of critics such as Shahane who intervene in the English discourse under the sign of Indianness. In this sense one can map a series of heterogeneous sites in which Indianness as difference is a structuring trope, beginning with the British representation of Indianness as subordinated otherness, then the Indian critics who propose a countertradition named Indianness, and then, in a more recent moment, critics such as Spivak and Guha who take issue with an essentialized notion of Indianness.

The feminist discussion of multivalence and positionality implies that because subjects are the sites of a variety of social relations, the interdependence and conflict between different inscriptions provide 
unique political opportunities to destabilize the power of any single particular inscription. Because the site of any cultural text is also crossed by multiple and unequal figurations, my interpretations have focused on those heterogeneous sites within French and British orientalism in which constructions of the Orient as Other are destabilized by intersecting or conflicting representations in the text itself, in intertextual dialogues, or from other discursive formations. In Lady Mary Wortley Montagu's Turkish Embassy Letters, both an eighteenth-century feminist discourse and a rhetoric about English class privilege provide discursive challenges to a prior tradition of seventeenth-century orientalist travel writing. The multivocality of the epistolary genre and the conflicting narratives about slaves and wives challenge the orientalizing framework of Montesquieu's Lettres persanes. Parody and multivalence in Flaubert's nineteenth-century work also contribute to the critique of orientalism as regressive sentimentality in L'éducation sentimentale.

Moments of heterogeneity occur in critical discourses, as well, and I have framed these moments of discursive instability in the dialogues between the Anglo-American and Indian critics, as well as in the postcolonial orientalist moment of Kristeva, Barthes, and Tel quel. In this last example the multivalent trope of the Orient as Other was reappropriated and refigured in the 1970 s by the French Left, which constituted China as its revolutionary Other. Although semiotics, French Maoism, and psychoanalysis deployed the trope in order to criticize particular apparatuses of power, the use of the orientalist formation inevitably upheld many of the logics and relationships that the Tel quel theorists wished to topple. I have suggested that there is much to learn about our contemporary critical moment from this example of orientalist discourse. From it we understand that multivalence or heterogeneity in themselves do not by any means ensure a transformation of the status quo, that colonialist logics persist despite decolonization, and furthermore, that theoretical discourses are not invulnerable to these logics. ${ }^{9}$

${ }^{9}$ For postcolonial articulations that succeed in shifting the discursive terrain in ways that Barthes, Kristeva, and the writers of Tel quel do not, it is necessary to look at the interventions of "native" or diaspora postcolonial writers who have formulated polyvocal models of resistance to the discourses that presume to define them. In this regard I have suggested a number of postcolonial theorists who critically address British orientalist discourse, but to this one must add the North African critique of French oriental- 
In this sense a consideration of heterogeneity and contradiction is likewise crucial to the framework within which the positions and responsibilities of critics are theorized. The notion of intellectual work must not be limited to the reproduction and restatement of a previous legacy of literary critical formulation. Rather, literary and cultural criticism must be made vital sites of productive, imaginative conflict between differing formulations and positions. New statements may not be enough, for although some may shift previously accepted paradigms, others will be neutralized and have little transforming effect. Therefore, it might be considered that the power of statements to alter specific cultural arrangements may not necessarily be due to an inherent quality or content, and may not even always be the exclusive result of the form of the statement. Rather, single articulations are apt to be less resistant to appropriation to the extent that they are not linked with other challenges to domination, and theories that are connected to a diversity of actions and practices are more powerful than those that are not connected. In other words, when intellectuals link theoretical concerns with activities inside and outside the university - when feminism and anticolonialism and antiracism are considered different but connected, and when otherness is not essentialized but is interpreted as a multivalent signifier making distinctly different relations of power possible at various historical momentsthen this critical work can contribute to the building of pressures and resistances against the voice of the one and the silencings of others.

ism articulated in the novels of Assia Djebbar, Tahar Ben Jelloun, and Leila Sebbar, among others, or the essays of Abdelkebir Khatibi. 